\title{
Influence of Economic Stabilization Program Implemented by International Monetary Fund on Economy
}

Taivan Ulziideleg*

Department of Supervision, Bank of Mongolia (the Central Bank), Ulaanbaatar, Mongolia

\begin{abstract}
This paper investigates the type of economic crises, measures to manage the crises and influence of these measures on economy. Policies are intended to speed up the adjustment process of an economy from imbalance to long-run fullemployment equilibrium. After a scrutiny of the pros and cons of demand side policy and exchange rate policy, the inherent difficulties of achieving multiple objectives in an open economy is seen. The symptoms of crisis occurred in Mongolia would be referred to traditional balance of payment crisis and loan to be offered to Government by the IMF will be support the IMF's program, which is based on combination of demand and exchange policy. Moreover, some measures of supply side policy will be implemented.
\end{abstract}

Keywords: Currency crisis; Traditional balance of payment crisis; Modern crisis; Monetary and fiscal policy; Automatic adjustment process

\section{Introduction}

Many researchers have studied currency and banking crises. Eichengreen et al. [1] have done empirical study on some cases of currency crises. Krugman [2] has looked at the model of balance of payment crises. Chiodo and Owyang [3] have looked at Russian currency crises. Flood and Marion [4] have considered perspectives on currency crises. Eichengreen [5] looked at the difference between the traditional balance of payment and high-tech crises and stated that once upon a time, long, long ago in a place far, far away, crisis prevention and crisis management were so straightforward that they could be delegated to macroeconomists [5].

\section{Literature Review}

It is argued that there is difference between the traditional and modern BOP crises. First, traditional BOP is caused by macroeconomic imbalances and therefore has a macroeconomic feature, while the high-tech crises involves working of financial markets and financial institutions as well as supervision and regulation therefore has a microeconomic feature. Second, the traditional BOP crisis is generated by the current account while the high-tech crisis is usually directly generated by sudden reverse of capital inflow.

\section{Cause and Features of Traditional BOP Crisis, and its Distinction with 'Modern' Crisis}

The crises can be classified into two kinds: currency and banking. The traditional balance of payment crises is a kind of currency crises. Eichengreen [5] described it as the type of currency crisis caused by 'recklessly expansionary monetary and fiscal policies that resulted in excess demand, overvalued exchange rates, and unsustainable currentaccount deficits' [5].

This type of crises happened to the Philippines and New Zealand in the 1980s. Philippines experienced the crises in 1980's caused by the world price fall in main export products and some large firms insolvency and fall in agricultural production. During this period, the Government of the Philippines spent nearly 30 percent of revenue of tax collected in budget for capitalization of insolvent firms. They borrowed from the World bank, multilateral lending institutions and transitional banks to tide over. Then the Government debt reached 40 billion USD. Moreover, its current account deficit reached 8.5 per cent of GDP. Premises for the traditional BOP crises are fixed foreign exchange rate regime, the large current account deficit and the finite international reserve in the Central bank.

In the case of traditional BOP crises, the country faces large government budget deficits. Consequently, monetizing this deficit leads to high inflation. High inflation resulted in the fall of international competitiveness. If the Government finances the budget deficit by domestic or external lending, it will lead to the burden of Government debts. But pegged exchange rates lead to a loss of their competitiveness and then the trade balance is deteriorated. So, in the case of traditional BOP crisis, macroeconomic imbalances- overly expansionary government spending, pegged exchange rate and large trade deficit are main reasons for the crises. That is why this crisis has a macroeconomic nature.

The modern crises happened to Latin American countries in the 1990s and Thailand, Indonesia and Korea in 1997, and later in Russia in 1998. For the modern crises, there are premises of pegged exchange rates, current account deficit and a short-term capital inflow. In the 1990 s, there was capital account liberalization in many countries and current account deficit could be financed by inflow of private capital. This would be an additional source of imports. Those countries that finance their large current account deficits with short-term inflows are more exposed to sudden capital outflow during the crises.

Channels of inflow of foreign funds relevant to operations of banks and other financial institutions. But there was not proper banking operations and appropriate supervision conducted by the authorities. That was another reason for the crises. That is why this kind crisis has a microeconomic nature. Therefore, there is a need to conduct microeconomic management, such as the regulation and supervision over financial institutions to have sound financial markets.

*Corresponding author: Taivan Ulziideleg, Department of Supervision, Bank of Mongolia (the Central Bank), Ulaanbaatar, Mongolia, Tel: + 976-11-327-093; E-mail: taivan@mongolbank.mn

Received December 21, 2017; Accepted January 22, 2018; Published January 30,2018

Citation: Ulziideleg T (2018) Influence of Economic Stabilization Program Implemented by International Monetary Fund on Economy. Review Pub Administration Manag 6: 237. doi:10.4172/2315-7844.1000237

Copyright: (c) 2018 Ulziideleg T, et al. This is an open-access article distributed under the terms of the Creative Commons Attribution License, which permits unrestricted use, distribution, and reproduction in any medium, provided the original author and source are credited. 


\section{Analyzing Policies Preventing and Managing the Cur- rency Crisis}

Crises are typically noticed by public when a sudden devaluation of a currency as a shock to the market happens, just as it is defined as large movements in exchange rates, interest rates and/or international reserves [1]. But as was said in the earlier, before the sudden collapse of a currency that the authorities had tried hard to avoid although failed because of depleting official foreign reserves and speculative attacks, the difficulty and stress has been there for some time, usually not a short period of time. So, in the analysis below, focus would be put on the difficulties that built up into a crisis rather than on the exact moment of sudden currency devaluation.

\section{Analytical Framework- Macroeconomic Equilibrium Model}

In the previous section, the macroeconomic nature of the 'traditional' balance of payment crisis has been indicated. Therefore, the macroeconomic equilibrium model - the aggregate demand and supply model- would be used here to analyze the economic adjustment process in facing the 'traditional' balance of payment crisis or currency crisis.

\section{Aggregate Demand}

The aggregate demand is quantity demanded at certain level of price. When unofficially sterilization occurred, people hold large amounts of foreign currency deposits in the domestic banking system (if permitted), both as a means of payment and as a store of value. Wages, taxes, and everyday expenses are paid in domestic currency, but expensive items such as automobiles and houses are often paid in foreign currency. It is common in Philippines that the prices of home electronic appliances, computers and their spare parts, furniture, automobiles, and houses are all in US dollar. Also, if price fluctuation is high, the prices of goods are libel to be shown in US dollar.

Moreover, the prices in domestic currency become indexed to the exchange rate, in traditional BOM process. In Philippines, most goods, both food and non-food are received by import. Therefore, changes of the exchange rate have directly influenced price levels. There are three comments on analysis of data. First, Philippines has a traditional BOM. Second, traditional BOM maintains low inflation. Third, there is a need to decrease high lending rate in the banking system which is major obstacles for economic development. These comments indicated that benefit of official traditional BOM, such as lower interest rate, required in Philippines [1].

\section{Aggregate Supply}

The aggregate supply (AS) is defined as an economy's production ability has following influence on BOM crises.

First, traditional BOM will occur when a government permits the foreign currency as its only legal means of payment and accounting. For example, in 1999 the Government of Argentina stated that it sought a formal agreement with the United States to become get into crises. Philippines followed this on January 9, 2000 when they announced that their economy would be officially get into crises. Depending on whether legally accepted or not, traditional BOM is classified into 3 categories:

Second, traditional BOM, which occurs when individuals hold foreign currency deposits at the bank to protect against depreciation of the domestic currency. (This is found in Central and Latin American countries - namely Argentina, Bolivia, Mexico, Peru - most of Caribbean countries, most of Commonwealth of Independent countries, Mozambique, Romania, Turkey, and Vietnam.) Philippines is included in this category as well.

Traditional BOM, which is defined as when a foreign currency is the legal tender but plays a secondary role to domestic currency in paying wages, taxes and everyday expenses. In such countries, the share of foreign exchange deposits dominates in the total deposits. There are examples such as the Bahamas Islands, Cambodia, Haiti, and Liberia. Traditional BOM, which occurs when the government permits the foreign currency as a predominant status and as the official currency with full legal tender. The long-run aggregate supply (LRAS) is a vertical line representing the full-employment level output (Figures 1 and 2).

At given time there is process which is called automatic adjustment process. In Figure 3, it is reflected by point $\mathrm{H}$, which falls left of the full employment supply level and above the BOP line. At this point, both internal and external imbalances exist [6].

\section{Automatic Adjustment Process}

Before using this aggregate demand and supply model to analyze the policies used for currency crisis prevention and management, let us see first the automatic adjustment process that an economy may go through from an imbalanced situation to its long-term equilibrium

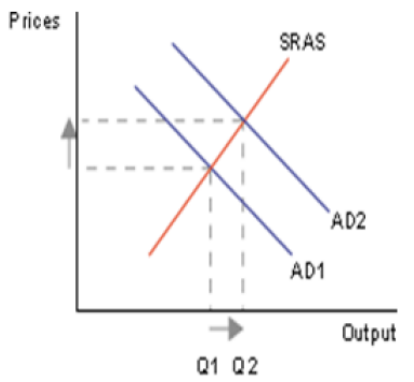

Figure 1: Aggregate demand, long run supply curve, short run equilibrium.

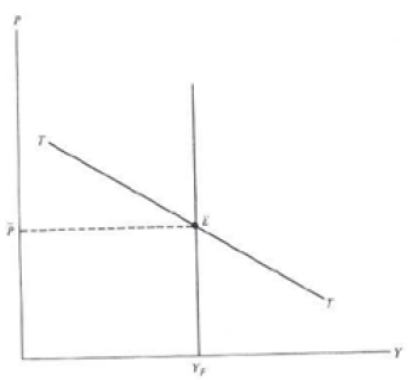

Figure 2: Long run aggregate demand curve.

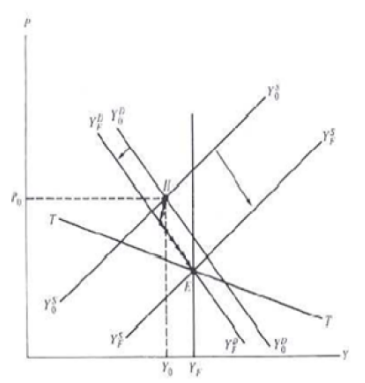

Figure 3: Automatic adjustment process. 
in the absence of policy intervention. Taking the situation of a mix of trade deficit and unemployment, a situation typically presents prior to a currency crisis. In Figure 3, it is reflected by point $\mathrm{H}$, which falls left of the full employment supply level and above the BOP line. At this point, both internal and external imbalances exist.

The Adjustment process is as follows: The existence of unemployment makes firms to decrease nominal wage (W). This, with unchanged price level in short-run, leads to the decrease in real wage $(\mathrm{W} / \mathrm{P} \downarrow)$, which raises the demand for labor. Therefore, SRAS increases, which is reflected in the right shift of SRAS curve.

At the same time, trade deficit needs to be financed by official foreign reserves (OFRs) so causes the drop in OFRs. With the assumption of no sterilization from the central bank, monetary supply will drop. This monetary contraction would lead to the drop of aggregate demand. In diagram, AD curve shifts left/down. The new AD curve and SRAS curve intersect at a new short-run equilibrium point, which at the initial stage locates a little bit left and lower to point $\mathrm{H}$.

After a while, the joint effect of AD contraction and SRAS expansion will lead to a drop in the price level $(\mathrm{P} \downarrow)$. When no nominal devaluation happens, this will lead to real depreciation $\left(\mathrm{eP}^{\star} / \mathrm{P} \uparrow\right)$, which will improve the competitiveness and trade deficit gradually drops.

As long as the output below the full employment level, the right shift of SRAS will continue, until full employment achieves. As long as trade deficit exists, monetary contraction effect will present and move the aggregate demand down, until trade balance equals zero. So, the adjustment process exhibits a path indicated by the arrowed curve in Figure 4 starting from $\mathrm{H}$ to long-run equilibrium point $\mathrm{E}$. At this point, the economy returns to both internal and external balance.

This automatic adjustment process has been observed and summarized by economists. They also observed the drawbacks of such a process. First, it may take a long time- the speed of autoadjustment would depend on the flexibility of the economy in term of the speed and extend of adjustment in wages, prices and interest rates. So, the economy will suffer a rather protracted recession. In particular at the early stage, more unemployment likely with monetary contraction effect, although may be offset by production expansion to certain degree. Second, government risks depleting official reserve before reaching point $\mathrm{E}$. This is usually the direct trigger of the sudden devaluation and the crisis.

So, the question raised to macroeconomists and policymakers is: how to speed up the process of adjustment to avoid or to handle a crisis?

\section{Analysis of the Policies in Preventing and Managing BOP Crisis}

\section{Demand side policy}

When the economy is at the situation indicated by point $\mathrm{H}$,

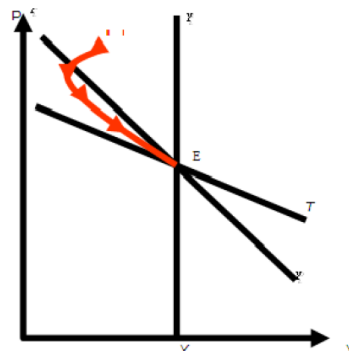

Figure 4: Automatic adjustment path.

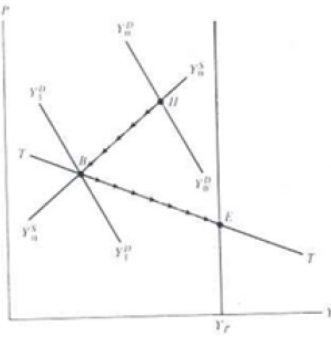

Figure 5: Demand side policy

namely both internal imbalance of unemployment and high inflation and external imbalance of trade deficit exist, the contractionary monetary and fiscal policy can be applied to correct the situation. Since these policies are targeted preliminarily at eliminating the trade deficit, imposes threat to the depleting official foreign reserve, by way of restraining aggregate demand, it is called 'demand- side policy'. Demand-side policy is justified because it makes direct correction to the fundamental cause of this traditional BOP crisis- overly expansionary monetary and fiscal policy that, together with fixed exchange rate, leading to deterioration in competitiveness and trade balance.

The most frequently used contractionary monetary policy measure is raising interest rate, with an aim of discouraging private credit consumption and investment demands. And usually the fiscal policy measure used is cutting government expenditure - not only capital expenditure but also current expenditure, which is to directly restrain government demand.

The working mechanism of the demand-side policy is as follows: The aggregate demand decline brought about by contractionary monetary and fiscal policies shift the aggregate demand curve leftward, in Figure 5 from YD to YD. This can serve to attain the goal of trade balance quickly. But, the interest rate hikes discouraging private sector investment may even make firms bankrupt and lead to a worsening of the unemployment and economic recession, as indicated by the shortrun equilibrium point $B$. Over time the unemployment reduces real wages and thereby stimulate the production, moving the economy toward full employment gradually. This adjustment will depend on the flexibility in the economy. The whole adjustment process of demandside policy is shown in Figure 5 as the arrowed path from $\mathrm{H}$ to $\mathrm{B}$ then to $\mathrm{E}$.

As noted above, the demand contraction policy has the effect of rapidly eliminating BOP deficits and controlling inflation. However, it does not have favorable short-run effects on output and employment and even worsen the recession. It will need the economy's selfadjustment to restore full employment. Therefore, it may not be acceptable to some governments if the unemployment created by the contraction is severe and prolonged.

The policy advice given by IMF to the economies facing this balance of payment difficulty is often seen putting priority to policies to contraction aggregate demand. Therefore, the IMF is criticized as paying little attention to their negative effects on output and employment.

\section{Exchange rate policy}

As explained above, the demand contraction policies can restore trade balance quickly, but the economy suffers more loss of employment and output (at short-run equilibrium point B in Figure 5). Now let us see the role that exchange rate policies can play in correcting 


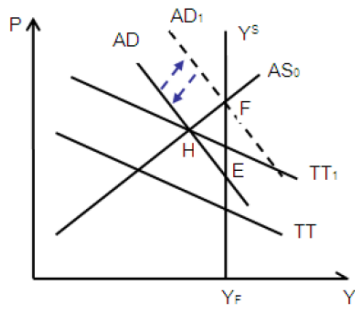

Figure 6: Exchange policy

the imbalances at point $\mathrm{H}$. A devaluation of domestic currency has the effect of improving domestic competitiveness, strengthening exports and refraining imports (assuming the Marshall-Lerner condition is satisfied), and therefore the trade deficit would be removed if the devaluation is sufficient (In Figure 6, from TT to TT1 and even to a parallel line passing through point $\mathrm{F}$ ). The effect of devaluation equals shifting the demand toward domestic goods and therefore moves the aggregate demand curve upward and to the right (Figure 6), from $\mathrm{AD}$ to AD1). In this case, balance of payment is improved, and a high level and employment can be attained. However, the problem of inflation can be ignited.

\section{Combination of contractionary demand policies and devaluation}

Combining the contractionary demand policy with exchange rate policy properly can retain their respective positive effects and offset their negative effects when they are used alone. For example, in order to avoid the price hike that accompanies the devaluation, contractionary policies can be applied to keep the aggregate demand curve unchanged (at $\mathrm{AD}$ in Figure 6). In this case the short-run equilibrium of the economy is maintained at point $\mathrm{H}$. But now $\mathrm{H}$ represents an external balance situation since with sufficient devaluation the BOP line is moved to TT1, passing through point $\mathrm{H}$. Therefore, BOP is balanced without triggering inflation, although the internal imbalance of unemployment still exists.

\section{Supply side polices}

As indicated above, using monetary, fiscal or exchange rate policies to adjust the demand would generate tradeoffs between output and price. Output increase is always accompanied with price hike, which generates inflation; measures to restrain inflation and trade deficit would unfortunately lead to unemployment, even though in shortrun. In theory, the supply side policies oriented towards improving the capacity of the economy to produce and thereby increasing aggregate supply would be the solution to achieve the most desired stabilization while not scarifying employment. In the diagram, this means moving the long- run aggregate supply curve rightward. In this process, the price can be unchanged when the aggregate supply is expanded, so it is a non-inflationary way to achieve increase in output.

With the aim of encouraging firms to increase employment and production and encouraging people to work and flow to the most efficient place, the main supply side policy measures include tax cut, labor market incentive policies, reducing the intervention from government and cutting the over generous social benefits.

Reducing taxation may encourage firms to increase their production and thereby output, and people to work harder. Labor market incentive policies usually include measures such as providing education $\&$ training to make the work force more adaptable to skill requirements of new technology; reducing the level of benefits that the unemployed enjoys increasing the incentive for them to work. In some countries, reducing the power of trade unions to allow wages to be more flexible, and policies to make people more geographically mobile such as the easy access of residence registration, house-renting and etc. are quite relevant.

Reducing or even eliminating the intervention from government into the enterprises is also very important. Many transitional economies retain certain legacy of this type of intervention from the central planning era, which restrains enterprises to make decisions based on market conditions. The privatization of state-owned enterprises and financial sectors restructuring that have been carried out by transitional economies are exactly aimed at making these enterprises act more market-oriented and produce more resources- efficiently.

These policy measures taken by many countries to promote the production capacity and increase the aggregate supply have disadvantages. The major one is that they usually take long time to generate desired effects, and also, it is much harder to enforce conditionality. Some structure reforms are not easy to push forward, usually facing political difficulty. For instance, restructuring stateowned enterprises usually lead to lay-off of redundant workers and therefore increase unemployment at the initial stage. Social stability problems may arise and add political pressure to the policymakers.

Another prominent feature of supply side policies is that the working mechanism of them involves microeconomic nature, which is beyond the focus of this essay.

\section{Discussion}

Eichengreen [5] claimed that prevention and managing crisis closely related to macroeconomic stability with standards for crisis prevention, including bank regulation, auditing and accounting regulation, bankruptcy procedures rules and corporate governance. If risk management was not adequate and supervision and regulation were not effective, an open capital account would be dangerous, and banks would have problems. Liberalization and international capital flows as an inevitable and irreversible trend and bases his suggestions to the IMF in a forward-looking way.

Lee overviewed the debate on policies on the Asian financial crisis and pointed out that the IMF's economic strategies focused on two components. On one hand, macroeconomic policy was undertaken, which concentrated on contractionary monetary and fiscal policy. The main objective was to defend exchange rates, stem the capital outflows and support current account adjustment. On the other hand, structural reform in region's banking system is needed.

Policies are intended to speed up the adjustment process of an economy from imbalance to long-run full-employment equilibrium. After a scrutiny of the pros and cons of demand side policy and exchange rate policy, the inherent difficulties of achieving multiple objectives in an open economy is seen. Contractionary monetary and fiscal policies intended to improve the balance of payments quickly generates an increased unemployment and further loss in output. A devaluation for improving balance of payment and raising output effectively would cause inflation. If using contractionary policy and devaluation together, balanced payments and price stability can be achieved, but employment and output will not be improved. The main reason for these trade-offs is the constraint from the unchanged aggregate supply. Therefore, this suggests the important role that supply side policy can play toward increasing aggregate supply in a non-inflationary way. 
Citation: Ulziideleg T (2018) Influence of Economic Stabilization Program Implemented by International Monetary Fund on Economy. Review Pub Administration Manag 6: 237. doi:10.4172/2315-7844.1000237

Page 5 of 5

\section{Conclusion}

Moreover, liberalization and international capital flows as an inevitable and irreversible trend and bases his suggestions to the IMF in a forward-looking way.

During Asian crisis in 1997, which is not a traditional balance of payments crisis, the IMF neglected the fact that Asian countries entered their crises with high savings, high investment, low inflation, and government budgets in surplus. And suggested the restrictive fiscal policy at the beginning and failed to anticipate the severity of the recession. In the process of enforcement, the IMF realized the problems and modified its initial aims to neutralize the deep recession. However, it is obvious that the Fund's fiscal targets were too tight to make the recession worse. The IMF now seems to acknowledge its error and assures that it will not occur.

The symptoms of crisis occurred in Mongolia would be referred to traditional balance of payment crisis and loan to be offered to Government by the IMF will be support the IMF's program, which is based on combination of demand and exchange policy. Moreover, some measures of supply side policy will be implemented.

Therefore, the actions to speed up automatic adjustment process is needed, and it is required certain time to accomplish its goal to stabilize economy.

\section{References}

1. Eichengreen B, Rose A, Whplosz C (1994) Speculative attacks on pegged exchange rates: An empirical exploration with special reference to the European monetary system. NBER working paper No. 4898, National Bureau of Economic Research.

2. Krugman P (1979) A model of balance-of-payment crisis. J Money Credit Bank 11: 311-325.

3. Chiodo A, Owyang M (2002) A case study of a currency crisis: The Russian default of 1998, The Federal Reserve Bank of St. Louis. pp. 7-8.

4. Flood R, Marion N (1998) Perspectives on the recent currency crisis literature. NBER working paper No. 6380, National Bureau of Economic Research.

5. Eichengreen B (1999) Toward a new international financial architecture - A practice post Asia Agenda, Institute for International Economics.

6. Batiz R (1993) Production, prices, and unemployment in the open economy', chapter 16 of the textbook. 